\title{
Persepsi dan Pemahaman Pelaku Usaha UMKM Terhadap Berlakunya Standar Akuntansi Keuangan Entitas Mikro Kecil Menengah di Kota Bandung
}

\author{
Received: \\ 17 Juni 2020 \\ Revision \\ received: \\ 25 Agustus 2020 \\ Accepted: $\quad$ The purpose of this study was to determine the perception and understanding of MSME \\ 25 Agustus 2020 centers business on the application of SAK EMKM at the MSME Business Center in \\ Bandung. In this study the data used are primary data, that is data obtained directly from \\ the object under study. Data obtained through questionnaires to several MSME business \\ center operastors int the city of Bandung. Sampling was carried out using the Sloving \\ formula, resulting in 336 MSME respondents. The regression model used in this study to use \\ Multiple Regression Analysis.The results of this study by t test (partial) showed that the \\ perception of MSME actors did not effect the implementation of SAK EMKM and the \\ understanding of MSME actors influenced the implementation of SAK EMKM. While the F \\ test (simultaneous) showed that the perception and understanding of MSME actors influence \\ the implementation of SAK EMKM.
}

Keywords: business centre, micro, small, medium financial accounting standards

\begin{abstract}
Abstrak:
Tujuan dari penelitian ini adalah untuk mengetahui persepsi dan pemahaman pelaku usaha sentra UMKM terhadap berlakunya SAK EMKM di Sentra Usaha UMKM Kota Bandung. Dalam penelitian ini data yang digunakan adalah berupa data primer, yaitu data yang diperoleh secara langsung dari objek yang diteliti. Data diperoleh melalui kuesioner kepada beberapa pelaku usaha sentra UMKM di Kota Bandung. Penarikan sampel dilakukan dengan menggunakan rumus Slovin, sehingga menghasilkan responden sebanyak 336 pelaku UMKM. Adapun model regresi yang dipergunakan dalam penelitian ini adalah dengan menggunakan Analisa Regresi Berganda. Hasil penelitian ini secara uji t (parsial) menunjukan bahwa persepsi pelaku UMKM tidak berpengaruh terhadap berlakunya SAK EMKM dan pemahaman pelaku UMKM berpengaruh terhadap berlakunya SAK EMKM. Sedangkan secara uji $\mathrm{F}$ (simultan) menunjukan bahwa persepsi dan pemahaman pelaku UMKM berpengaruh terhadap berlakunya SAK EMKM.
\end{abstract}

Kata Kunci: sentra usaha, standar akuntansi keuangan mikro kecil menengah

\section{Pendahuluan}

Jumlah pelaku usaha yang masuk kategori UMKM di Indonesia saat ini mengalami kemajuan yang sangat pesat sekali. Ada sekitar 59,2 juta UMKM, dan telah menyerap tenaga kerja nasional sekitar 97\% serta memberikan kontribusi PDB sekitar 57\%. Demikian juga untuk wilayah Propinsi Jawa Barat, khususnya di Kota Bandung, jumlah pelaku usaha UMKM menurut data dari Dinas Perdagangan dan Perindustrian tahun 2018 terdapat 2.076 unit usaha sentra UMKM.

Saat ini pelaku usaha sentra UMKM Kota Bandung banyak menghadapi berbagai masalah, 
salah satu masalahnya yaitu sulitnya pelaku usaha UMKM mendapatkan pinjaman dana yang berupa kredit bank sebagai tambahan modal usaha. Hal ini disebabkan lemahnya sumber daya manusia (SDM) dalam menyusun laporan keuangan. Kemampuan pelaku usaha UMKM dalam menghadapi kemajuan persaingan global memang sangat diperlukan karena hal ini dapat menjaga kestabilan UMKM dan perkonomian.

Besarnya kontribusi pengaruh sosialisasi SAK EMKM, tingkat pendidikan pemilik, persepsi pelaku UMKM dan pemahaman akuntansi terhadap implementasi SAK EMKM yaitu sebesar 57,5\%. Pemahaman akuntansi merupakan variabel yang paling dominan terhadap implementasi SAK EMKM (Salmiah, dkk. 2018)

Pemberlakuan MEA memberikan peluang kepada agar dapat bersaing dan mengembangkan UMKM secara komprehensif dan berkelanjutan, sehingga dapat menciptakan produk berdaya saing tinggi serta mempunyai manajemen yang tangguh dan berkualitas. Salah satu bentuk informasi yang dapat digunakan untuk mengetahui kondisi dan perkembangan suatu perusahaan adalah laporan keuangan yang dilaporkan setiap akhir periode sebagai laporan pertanggungjawaban atas pengelolaan suatu perusahaan (Auliyah, 2012).

Peran UMKM dalam perekonomian Indonesia yaitu menghasilkan output yang berguna bagi masyarakat. Namun UMKM dihadapkan pada salah satu kendala yang biasanya terjadi dalam usaha yaitu keterbatasan dalam pembuatan laporan keuangan. Setiap aktivitas yang dilakukan oleh UMKM memerlukan sebuah laporan keuangan yang mencerminkan kegiatan usahanya selama satu periode akuntansi.

Demi terpenuhinya kebutuhan informasi bagi UMKM maka Dewan Standar Akuntansi Keuangan Ikatan Akuntan Indonesia (DSAK IAI) menyusun dan mensahkan pada tanggal 24 Oktober 2016 yang berlaku efektif pada tanggal 1 Januari 2018 sebagai upaya mendukung kemajuan perekonomian Indonesia. Standar Akuntansi Keuangan Entitas Mikro, Kecil, dan Menengah (SAK EMKM) yang berisikan konsep yang tidak terlalu rumit atau dapat dikatakan sederhana dibandingkan dengan SAK ETAP yang selama digunakan oleh para UMKM. Dengan standar ini ini maka perusahaan kecil dan menengah mampu menyusun laporan keuangannya untuk mendapatkan dana dan pengembangan usaha (Hetika \& Mahmudah, 2017). Penggunaan SAK EMKM ini ditujukan untuk pengguna eksternal entitas mikro, kecil dan meneng ah seperti pemilik yang tidak terjun langsung dalam pengelolaan usaha dan kreditur,dimana penggunaan laporan keuangan pada UMKM cenderung tidak membutuhkan laporan keuangan rumit dan analisis laporan keuangan secara mendalam. (Sedangkan Murniati dan Sofiah, 2014) telah membuktikan pelaku UMKM menganggap penting informasi keuangan sebelum adanya sosialisasi SAK ETAP.

Dengan adanya SAK EMKM maka diharapkan UMKM lebih maju dan mandiri misalnya UMKM dapat menyeleggarakan pencatatan atas laporan keuangan usahanya. Mengingat informasi akuntansi mempunyai peranan penting untuk mencapai keberhasilan usaha, termasuk bagi UMKM. Informasi akuntansi dapat menjadi dasar yang andal untuk memperoleh kredit dari bank, tujuan pelaporan pajak maupun tujuan internal perusahaan seperti pengambilan keputusan ekonomis dalam pengelolaan usaha, antara lain keputusan pengembangan pasar, penetapan harga dan lain-lain. Dengan demikian diharapkan dengan adanya SAK EMKM akan meningkatkan profesionalitas dari UMKM.

Walaupun SAK EMKM dinyatakan lebih sederhana dan lebih mudah penerapannya dibandingkan dengan Standar Akuntansi Keuangan lainnya, tidaklah semudah yang dikatakan karena untuk menerapkan SAK EMKM dalam proses pelaporan keuangan tentunya memerlukan pemahaman yang cukup bagi pelaku UMKM. Apalagi kesadaran dan pemahaman pelaku usaha UMKM dalam melaksanakan praktik keuangan masih rendah dan memiliki banyak kendala dan kelemahan yang disebabkan tingkat pemahaman yang rendah dan kualitas sumber daya manuasia yang kurang memadai. Bagi UMKM terkait dengan penerapan SAK EMKM ini tentunya akan menambah wawasan pelaku UMKM terkait dengan SAK EMKM dan dapat meningkatkan kesadaran pelaku UMKM tentang pentingnya pencatatan atau pembukuan laporan keuangan sehingga dapat meningkatkan perkembangan usaha (Trisomantagani, dkk. 2017).

Pemahaman dan persepsi akan adanya standar akuntansi tentunya harus dipahami oleh pelaku UMKM. Sehingga pemahaman akuntansi merupakan variabel yang paling dominan terhadap SAK EMKM (Kusuma \& Lutfiany, 2018). Demikian juga persepsi pengusaha mikro kecil dan menengah 
secara simultan mempengaruhi penggunaan SAK EMKM (Nurfadilah, dkk. 2019).

Kota Bandung sebagai salah satu kota yang memiliki berbagai jenis usaha kreatif di tahun 2018 memiliki pelaku usaha UMKM yang tersebar di berbagai sentra usaha sebanyak 2.076 pelaku usaha. Saat ini pelaku UMKM di sentra usaha Kota Bandung banyak menghadapi berbagai masalah, salah satu masalahnya yaitu sulitnya UMKM mendapatkan pinjaman dana yang berupa kredit bank sebagai tambahan modal usaha. Hal ini disebabkan kurangnya persepsi dan pemahaman yang baik terhadap penerapan SAK EMKM yang diberlakukan tanggal 1 Januari 2018. Sehingga nantinya dengan adanya persepsi dan pemahaman yang baik mengenai pemberlakuan SAK EMKM, diharapkan para pelaku usaha sentra UMKM di Kota Bandung, dapat membuat laporan keuangan secara mandiri karena mudah dan sederhana, dimana laporan keuangan tersebut bisa digunakan untuk pengambilan keputusan maupun sebagai syarat untuk mendapatkan pinjaman dari perbankan.

\section{Kajian Literatur}

\section{Pengertian UMKM}

UMKM adalah unit usaha produktif yang berdiri sendiri, yang dilakukan oleh orang perorangan atau badan usaha disemua sektor ekonomi. Pada prinsipnya pembedaan antara usaha mikro, usaha kecil, usaha menengah, usaha besar umumnya didasarkan pada nilai aset awal (tidak termasuk tanah dan bangunan), omset rata-rata per tahun, atau jumlah pekerja tetap. Namun, definisi UMKM berdasarkan tiga alat ukur ini berbeda menurut negara. Oleh karena itu memang sulit membandingkan pentingnya atau peran UMKM antar negara. (Tambunan, 2012)

Di Indonesia definisi UMKM diatur dalam Undang-Undang Republik Indonsia Nomor 20 Tahun 2008 tentang UMKM. Dalam Bab 1 (Ketentuan Umum), pasal 1 dari UU tersebut, dinyatakan bahwa usaha mikro adalah usaha produktif milik orang-perorangan dan badan usaha perorangan yang memenuhi usaha mikro sebagaimana diatur dalam UU tersebut.

Pengertian UMKM menurut UU Nomor 20 Tahun 2008 menyebutkan :

1. Usaha Mikro adalah usaha produktif milik orang perorangan dan/ atau badan usaha perorangan yang memiliki kekayaan bersih paling banyak Rp50.000.000,00 tidak termasuk tanah dan bangunan tempat usaha atau memiliki hasil penjualan tahunan paling banyak Rp300.000.000,00

2. Usaha kecil adalah usaha ekonomi produktif yang berdiri sendiri, yang dilakukan oleh orang perorangan atau badan usaha yang bukan merupakan anak perusahaan atau bukan cabang perusahaan yang dimiliki, dikuasai atau menjadi bagian baik langsung maupun tidak langsung dari usaha menengah atau usaha besar yang memiliki kekayaan bersih lebih dari Rp50.000.000,00 sampai dengan paling banyak Rp 500.000.000,00 tidak termasuk tanah dan bangunan tempat usaha atau memiliki hasil penjualan tahunan lebih dari dari Rp300.000.000,00 sampai dengan paling banyak Rp2.500.000.000,00

3. Usaha menengah adalah usaha ekonomi produktif yang berdiri sendiri, yang dilakukan oleh orang perorangan atau badan usaha yang bukan merupakan anak perusahaan atau bukan cabang perusahaan yang dimiliki, dikuasai atau menjadi bagian baik langsung maupun tidak langsung dari usaha menengah atau usaha besar yang memiliki kekayaan bersih lebih dari Rp500.000.000,00 sampai dengan paling banyak Rp10.000.000.000 tidak termasuk tanah dan bangunan tempat usaha atau memiliki hasil penjualan tahunan lebih dari $\mathrm{Rp}$ 2.500.000.000,00 sampai dengan paling banyak Rp50.000.000.000,00

\section{Peranan dan Kontribusi UMKM di Indonesia}

Usaha Mikro, Kecil, dan Menengah (UMKM) di Indonesia memiliki peranan penting dalam perekonomian nasional, terutama dalam kontribusinya terhadap Produk Domestik Bruto (PDB). Mengingat pentingnya peranan UMKM dibidang ekonomi, sosial dan politik, maka saat ini perkembangan UMKM diberi perhatian cukup besar diberbagai belahan dunia.

Usaha Mikro, Kecil, dan Menengah (UMKM) mempunyai peranan yang strategis dalam pembangunan ekonomi nasional. Selain berperan dalam pertumbuhan ekonomi dan penyerapan tenaga kerja, UMKM juga berperan dalam pendistribusian hasil-hasil pembangunan.UMKM 
diharapkan mampu memanfaatkan sumber daya nasional, termasuk pemanfaatan tenaga kerja yang sesuai dengan kepentingan rakyat dan mencapai pertumbuhan ekonomi yang maksimum.

Peranan dalam bidang sosial bahwa UMKM disini mampu memberikan manfaat sosial yaitu mereduksi ketimpangan pendapatan, terutama di negara- negara berkembang. Peranan usaha kecil tidak hanya menyediakan barang-barang dan jasa bagi konsumen yang berdaya beli rendah, tetapi juga bagi konsumen perkotaan lain yang berdaya beli lebih tinggi. Selain itu, usaha kecil juga menyediakan bahan baku atau jasa bagi usaha menengah dan besar, termasuk pemerintah lokal. Tujuan sosial dari UMKM adalah untuk mencapai tingkat kesejahteraan minimum, yaitu menjamin kebutuhan dasar rakyat.

Peranan UMKM memang diakui memainkan peranan yang sangat penting di dalam pembangunan dan pertumbuhan ekonomi, tidak hanya di negara-negara yang sedang berkembang, tetapi juga di negara-negara maju. Di Indonesia, UMKM memberikan kontribusi tenaga kerja $90 \%$ lebih dan PDB sebesar $60 \%$ lebih.

\section{Permasalahan UMKM}

Permasalahan yang dihadapi UMKM sangat banyak dari modal, karyawan, bahan baku, akses perbankan dan juga pencatatan/pembukuan. Menurut Tambunan (2012:51) permasalahan yang dihadapi UMKM adalah :

"Terbatasnya modal dan akses dari sumber dan lembaga keuangan; masih rendahnya kualitas SDM pelaku usaha; kurangnya pengetahuan mengenai pencatatan; kemampuan manajerial dari para pelaku usaha; kemampuan pemasaran yang terbatas; akses informasi yang masih rendah, belum terjalin mitra yang saling menguntungkan antar UMKM; distribusi dan pengadaan bahan baku; biaya tinggi akibat prosedur administrasi dan birokratis yang kompleks."

\section{Laporan Keuangan}

Pengertian laporan keuangan menurut Fahmi (2015:2) adalah suatu informasi yang menggambarkan kondisi keuangan suatu perusahaan, dan lebih jauh informasi tersebut dapat dijadikan sebagai gambaran kinerja keuangan perusahaan. Dan Tujuan laporan keuangan menurut Fahmi (2015:5) adalah untuk memberikan informasi kepada pihak yang membutuhkan tentang kondisi suatu perusahaan dari sudut angka-angka dalam satuan moneter.

Jenis laporan keuangan menurut Kasmir (2014:9) adalah : 1). Balance Sheet (Neraca) Balance Sheet (neraca) merupakan laporan yang menunjukan posisi keuangan perusahaan pada tanggal tertentu. 2). Income Statement (Laporan Laba Rugi) Income Statement (Laporan laba rugi) merupakan laporan keuangan yang menggambarkan hasil usaha perusahaan dalam satu periode tertentu. 3). Laporan Perubahan Modal Laporan perubahan modal merupakan laporan yang berisi jumlah dan jenis modal yang dimiliki pada saat ini. 4). Laporan Arus Kas Laporan arus kas merupakan laporan yang menunjukan arus kas masuk dan kas keluar perusahaan. 5). Laporan Catatan Atas Laporan Keuangan Laporan catatan atas laporan keuangan merupakan laporan yang dibuat berkaitan dengan laporan keuangan yang disajikan.

\section{Standar Akuntansi Keuangan Entitas Mikro Kecil dan Menengah (SAK EMKM)}

Berdasarkan SAK EMKM (2016:1), Entitas mikro, kecil, dan menengah adalah entitas tanpa akuntabilitas publik yang signifikan, sebagaimana didefinisikan dalam Standar Akuntansi Keuangan Entitas Tanpa Akuntabilitas Publik (SAK ETAP), yang memenuhi definisi dan kriteria usaha mikro, kecil, dan menengah sebagaimana diatur dalam peraturan perundang-undangan yang berlaku di Indonesia, setidak-tidaknya selama dua tahun berturut- turut.

Menurut SAK EMKM (2016:2), tujuan laporan keuangan adalah untuk menyediakan informasi posisi keuangan dan kinerja keuangan suatu entitas yang bermanfaat bagi sejumlah besar pengguna dalam pengambilan keputusan ekonomi oleh siapapun yang tidak dalam posisi dapat meminta laporan keuangan khusus untuk memenuhi kebutuhan informasi tersebut. Pengguna tersebut meliputi penyedia sumber daya bagi entitas seperti kreditor maupun investor. Dalam memenuhi tujuannya, laporan keuangan juga menunjukkan pertanggungjawaban manajemen atas sumber daya yang dipercayakan kepadanya. 
Berdasarkan SAK EMKM (2016:9), laporan keuangan minimum terdiri dari: (a) Laporan posisi keuangan pada akhir periode; (b)Laporan laba rugi selama periode; (c) Catatan atas laporan keuangan, yang berisi tambahan dan rincian akun-akun tertentu yang relevan. Pada laporan keuangan yang disusun, entitas harus mengidentifikasi secara jelas setiap laporan keuangan dan catatan atas laporan keuangan.

\section{Persepsi dan Pemahaman}

Menurut Kothler (2013:179) menjelaskan bahwa persepsi adalah dimana kita memilih, mengatur, dan menterjemahkan masukan informasi untuk menciptakan gambaran dunia yang berarti. Sedangkan indikator pesepsi dalam persepsi EMKM adalah sebagai berikut :

1. Mengetahui perkembangan usaha.

2. Mendukung kepentingan usaha.

3. Meningkatkan pengelolaan usaha.

4. Memudahkan penerbitan laporan keuangan.

5. Mengevaluasi pelaporan akuntansi.

6. Penyajian informasi akuntansi.

7. Memberikan gambaran kondisi perusahaan.

8. Membantu pengambilan keputusan.

9. Memudahkan kredit bank

Sedangkan menurut Nana Sujana (2014:24), pemahaman dapat dibedakan ke dalam tiga kategori, pertama tingkat terendah adalah pemahaman terjemahan, kedua pemahaman penafsiran dan ketiga adalah tingkat tertinggi adalah pemahaman ekstraporasi.

Ini berarti bahwa orang yang memiliki pemahaman standar akuntansi adalah orang yang pandai dan mengerti benar standar akuntansi. Sehingga, pemahaman akuntansi berarti kemampuan untuk mengukur, mengklasifikasikan (membedakan), dan mengikhtisarkan (menyajikan) unsurunsur laporan keuangan. SAK EMKM adalah suatu standar akuntansi yang digunakan bagi entitas mikro, kecil dan menengah yang menerbitkan laporan keuangan untuk tujuan umum bagi pengguna eksternal. Maka pemahaman SAK EMKM merupakan suatu kemampuan seseorang untuk mengukur, mengklasifikasi (membedakan) dan mengikhtisarkan penyajian unsurunsur laporan keuangan sesuai dengan ketentuan yang berlaku dalam SAK EMKM.

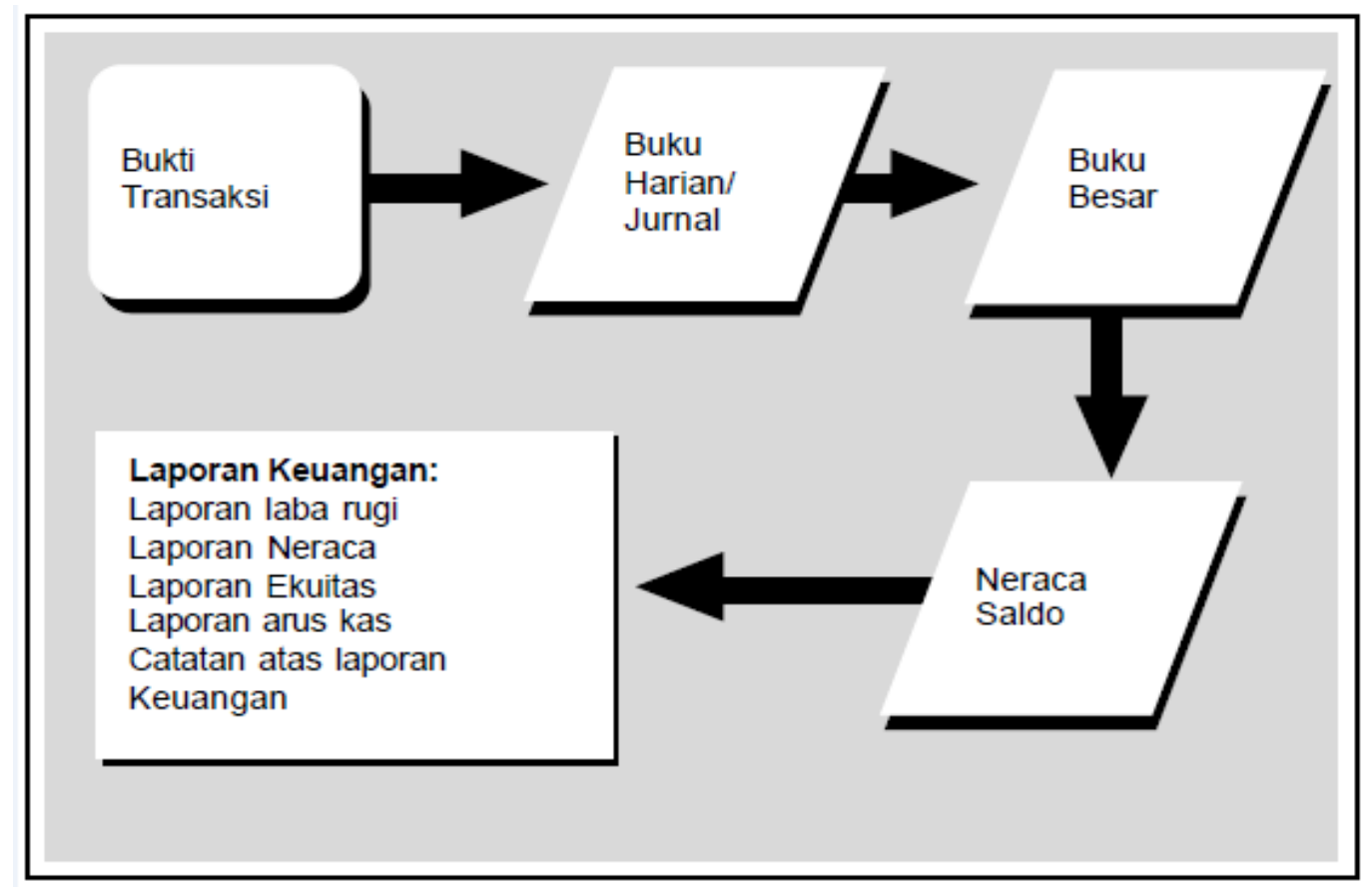

Gambar 1. Proses Akuntansi (data yang diolah) 


\section{Metode Penelitian}

\section{Objek Penelitian}

Yang menjadi objek penelitian adalah pelaku usaha sentra UMKM yang tersebar di sentra usaha di Kota Bandung. Adapun usahanya adalah dalam pembuatan sepatu, produksi tahu, produksi kain, pembuatan boneka, pembuatan kain rajut, pembuatan celana jean's, pembuatan kaos dan sablon.

\section{Jenis dan Sumber Data}

Jenis data yang digunakan dalam penelitian ini adalah data kuantitatif. Menurut Sugiyono (2017:13) Data Kuantitatif adalah data yang berwujud angka-angka. Hal ini dilakukan dengan cara mengumpulkan data-data yang merupakan faktor pendukung terhadap pengaruh antara variabelvariabel yang bersangkutan dengan cara membagikan kuesioner kemudian dianalisis dengan menggunakan alat uji statistik.

Sedangkan sumber data yang digunakan dalam penelitian ini adalah berupa data primer, yaitu data yang diperoleh secara langsung dari objek yang diteliti. Data diperoleh melalui kuesioner kepada beberapa pelaku usaha sentra UMKM di Kota Bandung. Menurut Anwar Sanusi (2011:104) menyatakan bahwa, "Data primer adalah data yang pertama kali dicatat dan dikumpulkan oleh peneliti."

\section{Teknik Pengumpulan Data}

Data yang diperoleh langsung peneliti berupa data primer dan data sekunder, yaitu:

1. Data primer

Menurut Danang Suyanti (2013). Data primer yaitu data yang diperoleh secara langsung dari responden (objek penelitian). Data primer dapat diperoleh melalui wawancara, kuisioner dan observasi lapangan berdasarkan jadwal penelitian.

2. Data Sekunder

Menurut Danang Suyanti (2013). Data sekunder diperoleh melalui data yang telah diteliti dan dikumpulkan oleh pihak lain yang berkaitan dengan masalah penelitian, seperti : jumlah pemilik usaha sentra UMKM di Kota Bandung yang berasal dari Dinas Perdagangan dan Perindustrian Kota Bandung dan pedoman standar akuntansi untuk UMKM (SAK EMKM).

\section{Teknik Penarikan Sampel}

Menurut Sugiyono (2017:80) menyatakan bahwa populasi adalah sebagai berikut:"Wilayah generalisai yang terdiri atas : objek atau subjek yang mempunyai kualitas dan karakteristik tertentu yang ditetapkan oleh peneliti untuk dipelajari dan kemudian ditarik kesimpulannya."

Maka yang menjadi populasi dalam penelitian ini adalah jumlah pelaku usaha sentra UMKM yang tersebar di beberapa sentra usaha di Kota Bandung yaitu 2.076 pelaku usaha sentra. Definisi sampel menurut Sugiyono (2017:81) adalah: "Sampel adalah bagian dari jumlah dan karakteristik yang dimiliki oleh populasi tersebut".

Penentuan sampel ditentukan dengan menggunakan ketentuan rumus Slovin (Husein Umar, 2011:78) sebagai berikut :

$$
\mathrm{n}=\frac{N}{1+N \kappa^{2}}
$$

Keterangan :

$\mathrm{n}=$ ukuran sampel

$\mathrm{N}=$ ukuran populasi

$\alpha=$ persen kelonggaran ketidaktelitian karena kesalahan pengambilan sampel yang masih dapat ditolerir atau diinginkan, dalam penelitian ini adalah $5 \%$. 
Berdasarkan jumlah pelaku usaha sentra UMKM yang tersebar di sentra usaha Kota Bandung sebesar 2.076 pelaku usaha sentra dengan margin of error sebesar 5\% adalah:

$$
\begin{aligned}
\mathrm{n} & =\frac{N}{1+N(\alpha)^{2}} \\
\mathrm{n} & =\frac{2.076}{1+2.076(0,05)^{2}} \\
\mathrm{n} & =\frac{2.076}{1+2.076(0,0025)} \\
\mathrm{n} & =\frac{2.076}{1+5} \\
\mathrm{n} & =\frac{2.076}{6} \\
\mathrm{n} & =335,3796 \\
\mathrm{n} & =336
\end{aligned}
$$

Jadi jumlah sampel yang digunakan dalam penelitian ini sebanyak 336 pelaku usaha sentra UMKM di Kota Bandung.

Tabel 1 Jumlah Populasi dan Sampel Penelitian

\begin{tabular}{|c|l|l|c|c|}
\hline No. & \multicolumn{1}{|c|}{ Nama Sentra } & \multicolumn{1}{|c|}{ Alamat } & Populasi & Sampel \\
\hline 1. & Sentra Usaha Rajut Binong & Jl. Binong Jati Bandung & 293 & 47 \\
\hline 2. & Sentra Usaha Jean's Cihamapelas & Jl. Cihampelas Bandung & 59 & 10 \\
\hline 3. & Sentra Tekstil Cigondewah & Jl. Cigondewah Bandung & 313 & 51 \\
\hline 4. & Sentra Boneka Sepatu Cibaduyut & Jl. Cibaduyut Bandung & 577 & 93 \\
\hline 5. & Sentra Usaha Kaos dan Sablon Suci & Jl. PHH Mustofa Bandung & 409 & 63 \\
\hline 6. & Sentra Usaha Tahu Cibuntu & Jl. Babakan Ciparay Bandung & 408 & 66 \\
\hline 7. & Sentra Usaha Boneka Sukamulya & Jl. Sukamulya Indah Bandung & 17 & 3 \\
\hline \multicolumn{2}{|r|}{ Jumlah } & $\mathbf{1 . 2 3 5}$ & $\mathbf{3 3 6}$ \\
\hline
\end{tabular}

\section{Hasil dan Pembahasan}

\section{Hasil Penelitian}

Hasil penelitian yang diperoleh dari responden dikelompokan menjadi beberapa kategori yaitu responden laki-laki sebanyak 240 orang $(71,4 \%)$ dan perempuan sebanyak 96 orang $(28,6 \%)$. Tingkat pendidikan untuk SMA/Sederajat sebanyak 284 responden $(84,5 \%)$ dan pendidikan Perguruan Tinggi sebanyak 52 responden $(15,5 \%)$. Kategori berdasarkan umur perusahaan sebanyak 312 responden lebih dari 5 tahun (92,9\%), sampai dengan 5 tahun sebanyak 24 responden $(7,1 \%)$. Sedangkan dari jumlah karyawan adalah sebanyak 199 responden merupakan perusahaan yang memiliki karyawan lebih dari 5 orang $(59,2 \%)$ sedangkan yang memiliki sampai dengan 5 karyawan sebanyak 137 responden $(40,8 \%)$.

\section{Hasil Analisis Deskriptif}

Untuk menjawab rumusan masalah dalam penelitian ini, setiap jawaban responden diberi nilai berdasarkan skala likert kemudian dilakukan perhitungan untuk menentukan interpretasi skor sebagai berikut:

\begin{tabular}{|c|c|c|c|c|c|c|c|c|}
\hline \multirow{2}{*}{ No } & \multirow{2}{*}{ Pertanyaan } & \multicolumn{4}{|c|}{ Frekuensi } & \multirow{2}{*}{$\begin{array}{l}\text { Jumlah } \\
\text { (N) }\end{array}$} & \multirow{2}{*}{$\begin{array}{l}\text { Skor } \\
\text { Total }\end{array}$} & \multirow{2}{*}{$\begin{array}{l}\text { Skor } \\
\text { Ideal }\end{array}$} \\
\hline & & STS & TS & $\mathrm{S}$ & SS & & & \\
\hline 1. & Berlakunya SAK EMKM 01- & 5 & 114 & 1076 & 25 & 336 & 1220 & 1344 \\
\hline
\end{tabular}

Jumlah responden : 336 orang

Skor tertinggi : 4

Skor terendah $: 1$

Jumlah kumulatif tertinggi : 336 x $4=1344$

Jumlah kumulatif terendah : $336 \times 1=336$

Tabel 2 Berlakunya SAK EMKM 


\begin{tabular}{|c|c|c|c|c|c|c|c|c|}
\hline & $01-2018$ & & & & & & & \\
\hline 2. & $\begin{array}{l}\text { SAK EMKM berlaku untuk } \\
\text { pengusaha UMKM }\end{array}$ & 2 & 34 & 1236 & 40 & 336 & 1312 & 1344 \\
\hline 3. & $\begin{array}{l}\text { Jenis Laporan SAK EMKM } \\
\text { (Laporan Posisi Keuangan, } \\
\text { Laba Rugi, Catatan Atas } \\
\text { Laporan Keuangan) }\end{array}$ & 2 & 18 & 1260 & 50 & 336 & 1330 & 1344 \\
\hline 4. & $\begin{array}{l}\text { SAK EMKM lebih mudah } \\
\text { dari Standar Akuntansi yang } \\
\text { lain (SAK ETAP) }\end{array}$ & 3 & 54 & 1168 & 70 & 336 & 1295 & 1344 \\
\hline 5. & $\begin{array}{lrr}\text { Penyusunan } & \text { Laporan } \\
\text { Keuangan } & \text { secara } & \text { terus } \\
\text { menerus } & & \\
\end{array}$ & 2 & 376 & 556 & 35 & 336 & 969 & 1344 \\
\hline 6. & $\begin{array}{lcc}\text { Infromasi } & \text { Akuntansi } & \text { yang } \\
\text { dihasilkan } & \text { sesuai } & \text { SAK } \\
\text { EMKM } & & \\
\end{array}$ & 2 & 646 & 24 & 25 & 336 & 697 & 1344 \\
\hline 7. & $\begin{array}{l}\text { SAK } \\
\text { dilaksanakan perusahaan }\end{array}$ & 3 & 644 & 24 & 25 & 336 & 696 & 1344 \\
\hline 8. & $\begin{array}{l}\text { Hasill Pelaksanaan SAK } \\
\text { EMKM } \quad \text { menggambarkan } \\
\text { kondisi dalam dan luar } \\
\text { Keuangan Perusahaan }\end{array}$ & 2 & 642 & 28 & 30 & 336 & 702 & 1344 \\
\hline \multicolumn{7}{|c|}{ Rata-rata } & 1028 & \\
\hline \multicolumn{7}{|c|}{ Nilai Tertinggi } & 1330 & \\
\hline \multicolumn{7}{|c|}{ Nilai Terendah } & 696 & \\
\hline
\end{tabular}

Keterangan: a. Skor Ideal =n x $4=336$ x $4=1344$

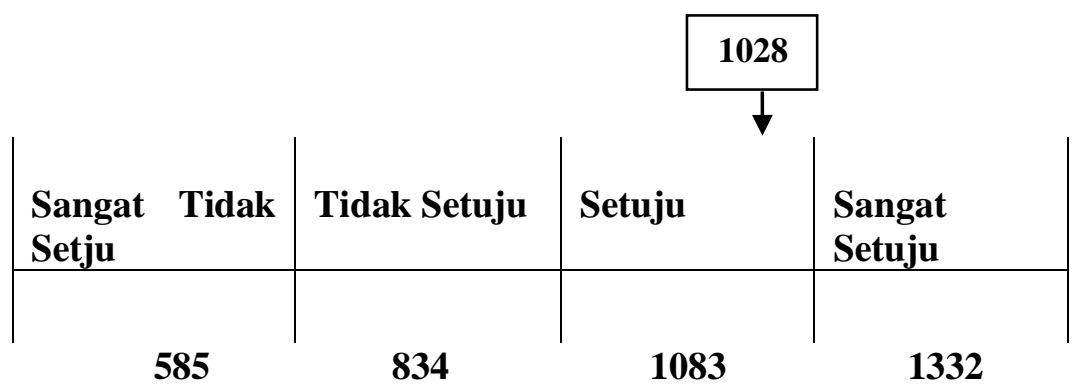

Gambar 1 Garis Kontinum

Berdasarkan Tabel 2 dapat diketahui skor rata-rata pernyataan kuesioner mengenai berlakunya SAK EMKM sebesar 1028. Skor terendah terdapat pada pernyataan kuesioner nomor 7 mengenai: SAK EMKM telah dilaksanakan perusahaan, pada pernyataan tersebut mendapatkan skor terendah sebesar 696 artinya pada pertanyaan kuesioner nomor 7 mendapatkan respon Tidak Setuju. Sehingga Berdasarkan hasil penelitan tersebut dapat ditarik kesimpulan bahwa mayoritas Sentra UMKM Di Kota Bandung yang menjadi sampel dalam penelitian menyatakan bahwa perusahaannya tidak menggunkan SAK EMKM dalam proses penyajian Laporan Keuangannya, hal tersebut dikarenakan kurangnya pengetahuan mengenai SAK EMKM. Hal ini sesuai dengan permasalahan yang dihadapi oleh sebagian besar UMKM yaitu kurangnya pengetahuan terhadap suatu pencatatan/pembukuan (Tambunan, 2012).

Skor tertinggi pada pernyataan kuesioner nomor 3 mengenai: Jenis Laporan SAK EMKM terdiri Laporan Posisi Keuangan, Laba Rugi, Catatan Atas Laporan Keuangan, memperoleh Skor 1330. Hal tersebut mengungkapkan bahwa sebagian besar Sentra UMKM Di kota Bandung sepakat bahwa Laporan SAK EMKM terdiri dari 3 laporan, yaitu Laporan Posisi Keuangan, Laba Rugi, Catatan Atas Laporan Keuangan. 
Tabel 3 Persepsi Pelaku Sentra UMKM Berlakunya SAK EMKM

\begin{tabular}{|c|c|c|c|c|c|c|c|c|}
\hline \multirow{2}{*}{ No } & \multirow{2}{*}{ Pertanyaan } & \multicolumn{4}{|c|}{ Frekuensi } & \multirow{2}{*}{$\begin{array}{l}\text { Jumlah } \\
(\mathrm{N})\end{array}$} & \multirow{2}{*}{$\begin{array}{l}\text { Skor } \\
\text { Total }\end{array}$} & \multirow{2}{*}{$\begin{array}{l}\text { Skor } \\
\text { Ideal }\end{array}$} \\
\hline & & STS & TS & $\mathrm{S}$ & SS & & & \\
\hline 1. & $\begin{array}{l}\text { Dapat mengetahui } \\
\text { perkembangan usaha }\end{array}$ & 0 & 4 & 912 & 530 & 336 & 1446 & 1344 \\
\hline 2. & $\begin{array}{l}\text { Mendukung kepentingan } \\
\text { usaha }\end{array}$ & 0 & 0 & 908 & 545 & 336 & 1453 & 1344 \\
\hline 3. & $\begin{array}{l}\text { Meningkatkan pengelolaan } \\
\text { perusahaan }\end{array}$ & 0 & 0 & 928 & 520 & 336 & 1448 & 1344 \\
\hline 4. & $\begin{array}{l}\text { Memudahkan penerbitan } \\
\text { Laporan Keuangan }\end{array}$ & 0 & 122 & 948 & 190 & 336 & 1260 & 1344 \\
\hline 5. & $\begin{array}{l}\text { Dapat dipahami setiap } \\
\text { laporannya }\end{array}$ & 0 & 26 & 1056 & 295 & 336 & 1377 & 1344 \\
\hline 6. & $\begin{array}{l}\text { Mengevaluasi pelaporan } \\
\text { akuntansi secara periodik }\end{array}$ & 2 & 104 & 1008 & 150 & 336 & 1264 & 1344 \\
\hline 7. & $\begin{array}{l}\text { Penyajian informasi } \\
\text { akuntansi secara keseluruhan }\end{array}$ & 2 & 602 & 44 & 110 & 336 & 758 & 1344 \\
\hline 8. & $\begin{array}{l}\text { Memberikan gambaran } \\
\text { kondisi perusahaan baik } \\
\text { yang lalu maupun sekarang }\end{array}$ & 1 & 90 & 900 & 325 & 336 & 1316 & 1344 \\
\hline 9. & $\begin{array}{l}\text { Membantu pengambilan } \\
\text { keputusan }\end{array}$ & 0 & 12 & 1036 & 355 & 336 & 1403 & 1344 \\
\hline 10. & $\begin{array}{l}\text { Memudahkan memperoleh } \\
\text { kredit Bank }\end{array}$ & 10 & 70 & 1032 & 165 & 336 & 1277 & 1344 \\
\hline \multicolumn{7}{|c|}{ Rata-rata } & 1300 & \\
\hline \multicolumn{7}{|c|}{ Nilai Tertinggi } & 1453 & \\
\hline \multicolumn{7}{|c|}{ Nilai Terendah } & 758 & \\
\hline
\end{tabular}

Keterangan: a. Skor Ideal $=\mathrm{n} \times 4=336 \times 4=1344$

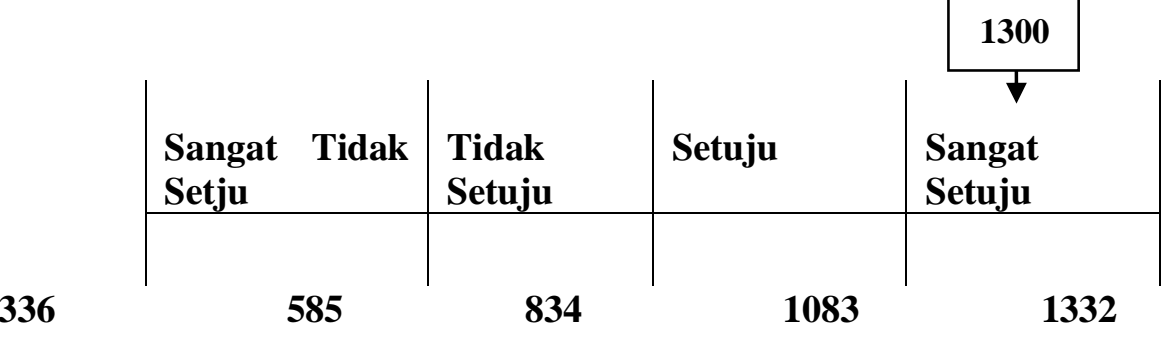

Gambar 2 Garis Kontinum

Berdasarkan Tabel 3 dapat diketahui skor rata-rata pernyataan kuesioner mengenai Persepsi Pelaku Sentra UMKM tentang berlakunya SAK EMKM sebesar 1300. Skor terendah terdapat pada pernyataan kuesioner nomor 7 mengenai: Penyajian Informasi Akuntansi Secara Keseluruhan sebesar 758 artinya pada pertanyaan kuesioner nomor 7 mendapatkan respon Tidak Setuju. Sehingga Berdasarkan hasil penelitan tersebut dapat ditarik kesimpulan bahwa mayoritas Sentra UMKM Di Kota Bandung yang menjadi sampel dalam penelitian menyatakan bahwa perusahaannya tidak menyajikan informasi akuntansi secara keseluruhan, hal tersebut dikarenakan lemahnya sisi manajemen dalam sentra UMKM dan ketidakmampuan pihak Pelaku Sentra UMKM dalam proses penyajian Informasi Akuntansi. Hal ini sesuai dengan permasalahan yang dihadapi oleh sebagian besar UMKM (Tambunan, 2012), yaitu kemampuan manajerial dari para pelaku usaha yang masih kurang.

Skor tertinggi pada pernyataan kuesioner nomor 2 mengenai: Meningkatkan Pengelolaan Perusahaan, memperoleh Skor 1453. Hal tersebut mengungkapkan bahwa sebagian besar Sentra UMKM Di kota Bandung selalu meningkatkan pengelolaan perusahaan untuk kemajuan Sentranya. 
Tabel 4 Pemahaman Pelaku Sentra UMKM Berlakunya SAK EMKM

\begin{tabular}{|c|c|c|c|c|c|c|c|c|}
\hline \multirow{2}{*}{ No } & \multirow{2}{*}{ Pertanyaan } & \multicolumn{4}{|c|}{ Frekuensi } & \multirow{2}{*}{$\begin{array}{l}\text { Jumlah } \\
\text { (N) }\end{array}$} & \multirow{2}{*}{$\begin{array}{l}\text { Skor } \\
\text { Total }\end{array}$} & \multirow{2}{*}{$\begin{array}{l}\text { Skor } \\
\text { Ideal }\end{array}$} \\
\hline & & STS & TS & $\mathrm{S}$ & SS & & & \\
\hline 1. & Paham SAK EMKM & 8 & 618 & 56 & 25 & 336 & 707 & 1344 \\
\hline 2. & $\begin{array}{l}\text { Paham proses pencatatan } \\
\text { akuntansi }\end{array}$ & 1 & 204 & 860 & 90 & 336 & 1155 & 1344 \\
\hline 3. & $\begin{array}{l}\text { Pencatatan akuntansi telah } \\
\text { di laksanakan }\end{array}$ & 0 & 46 & 1088 & 205 & 336 & 1339 & 1344 \\
\hline 4. & $\begin{array}{lc}\text { Pencatatan } & \text { akuntansi di } \\
\text { laksanakan } & \text { secara manual }\end{array}$ & 0 & 338 & 472 & 245 & 336 & 1055 & 1344 \\
\hline 5. & $\begin{array}{l}\text { Pencatatan akuntansi } \\
\text { dilaksanakan computer }\end{array}$ & 0 & 344 & 656 & 0 & 336 & 1000 & 1344 \\
\hline 6. & $\begin{array}{lr}\text { Pencatatan } & \text { akuntansi } \\
\text { dilaksanakan } & \text { secara program } \\
\text { akuntansi } & \end{array}$ & 2 & 430 & 464 & 15 & 336 & 911 & 1344 \\
\hline 7. & $\begin{array}{l}\text { Pendidikan berlatar belakang } \\
\text { akuntansi }\end{array}$ & 4 & 608 & 84 & 35 & 336 & 731 & 1344 \\
\hline 8. & $\begin{array}{l}\text { Pencatatan akuntansi telah } \\
\text { sesuai dengan SAK EMKM }\end{array}$ & 8 & 622 & 60 & 10 & 336 & 700 & 1344 \\
\hline 9. & $\begin{array}{l}\text { Berpengalaman kerja kurang } \\
\text { dari } 5 \text { tahun }\end{array}$ & 3 & 610 & 56 & 70 & 336 & 739 & 1344 \\
\hline 10. & $\begin{array}{l}\text { Berpengalaman kerja lebih } 5 \\
\text { tahun }\end{array}$ & 3 & 118 & 772 & 405 & 336 & 1298 & 1344 \\
\hline \multicolumn{7}{|c|}{ Rata-rata } & 963,5 & \\
\hline \multicolumn{7}{|c|}{ Nilai Tertinggi } & 1339 & \\
\hline \multicolumn{7}{|c|}{ Nilai Terendah } & 700 & \\
\hline
\end{tabular}

Keterangan: a. Skor Ideal $=\mathrm{n}$ x $4=336$ x $4=1344$

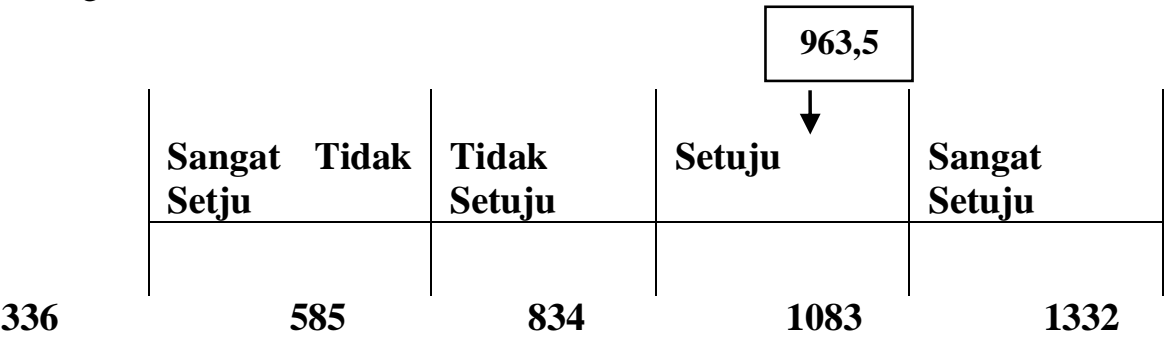

Gambar 3 Garis Kontinum

Berdasarkan Tabel 4 dapat diketahui skor rata-rata pernyataan kuesioner mengenai pemahaman pelaku Sentra UMKM tentang berlakunya SAK EMKM sebesar 963,5. Skor terendah terdapat pada pernyataan kuesioner nomor 8 mengenai: Pencatatan Akuntansi Sudah Sesuai Dengan SAK EMKM skor terendah sebesar 700, artinya pada pertanyaan kuesioner nomor 8 mendapatkan respon Tidak Setuju. Sehingga Berdasarkan hasil penelitan tersebut dapat ditarik kesimpulan bahwa mayoritas Sentra UMKM Di Kota Bandung yang menjadi sampel dalam penelitian menyatakan bahwa pencatatan Akuntansi dalam penyajian Laporan Keuangannya tidak sesuai dengan SAK EMKM, hal tersebut dikarenakan kurangnya pengetahuan mengenai SAK EMKM. Hal ini sesuai dengan permasalahan yang dihadapi oleh sebagian besar UMKM yaitu kurangnya pengetahuan terhadap suatu pencatatan/pembukuan (Tambunan, 2012).

Skor tertinggi pada pernyataan kuesioner nomor 3 mengenai: Pencatatan Akuntansi Telah Dilaksanakan, memperoleh Skor 1339. Hal tersebut mengungkapkan bahwa sebagian besar Sentra UMKM Di kota Bandung sudah melaksanakan pencatatn Akuntansi dalam penyajian Laporan Keuangannya.

\section{Analisis Regresi Berganda}


Analisis ini digunakan untuk mengetahui pengaruh beberapa variabel independen $(\mathrm{X})$ terhadap variabel dependen $(\mathrm{Y})$. Model regresi berganda yang akan dibentuk adalah sebagai berikut:

$$
\begin{array}{ll}
\mathrm{Y}=\alpha+\beta_{1} \mathrm{X}_{1}+\beta_{2} \mathrm{X}_{2}+\mathrm{e} \\
\text { Dimana: } & \\
\mathrm{Y} & =\text { Berlakunya SAK EMKM } \\
\alpha & =\text { Konstanta } \\
\beta_{1}, \beta_{2}, \beta_{3}, & =\text { Koefisien regresi } \\
\mathrm{X}_{1} & =\text { Persepsi Pelaku Sentra UMKM } \\
\mathrm{X}_{2} & =\text { Pemahaman Pelaku Sentra UMKM } \\
\mathrm{e} & =\text { Error }
\end{array}
$$

\begin{tabular}{|c|c|c|c|c|c|c|c|}
\hline \multirow[b]{2}{*}{ Model } & \multicolumn{2}{|c|}{$\begin{array}{l}\text { Unstandardized } \\
\text { Coefficients }\end{array}$} & \multirow{2}{*}{$\begin{array}{l}\text { Standardized } \\
\text { Coefficients } \\
\text { Beta }\end{array}$} & \multirow[b]{2}{*}{$\mathrm{t}$} & \multirow[b]{2}{*}{ Sig. } & \multicolumn{2}{|c|}{$\begin{array}{l}\text { Collinearity } \\
\text { Statistics }\end{array}$} \\
\hline & B & $\begin{array}{l}\text { Std. } \\
\text { Error }\end{array}$ & & & & Tolerance & VIF \\
\hline $1 \quad$ (Constant $)$ & 18,692 & 2,050 & & 9,118 & 0,000 & & \\
\hline PERSEPSI & & & & & & & \\
\hline $\begin{array}{l}\text { PELAKU } \\
\text { SENTRA UMKM }\end{array}$ & 0,014 & 0,052 & 0,016 & 0,269 & 0,788 & 0,872 & 1,147 \\
\hline $\begin{array}{l}\text { PEMAHAMAN } \\
\text { PELAKU } \\
\text { SENTRA UMKM }\end{array}$ & 0,168 & 0,053 & 0,182 & 3,160 & 0,002 & 0,872 & 1,147 \\
\hline
\end{tabular}

Hasil perhitungan regresi linier berganda adalah sebagai berikut :

Tabel 5 Hasil Analisis Regresi Berganda

a. Dependent Variable: BERLAKUNYA SAK EMKM

Dari output di atas diketahui nilai konstanta dan koefisien regresi sehingga dapat dibentuk persamaan regresi linier berganda sebagai berikut:

$$
\mathrm{Y}=18,692+0,014 \mathrm{X}_{1}+0,168 \mathrm{X}_{2}
$$

Persamaan di atas dapat diartikan sebagai berikut:

$\alpha=18,692$ artinya jika variabel persepsi pelaku sentra Umkm (X1) dan pemahaman pelaku sentra Umkm (X2) bernilai nol (0), maka nilai variabel berlakunya SAK EMKM (Y) diperoleh 18,692 .

$B_{1}=0,014 \quad$ artinya setiap penambahan satu satuan variabel persepsi pelaku sentra Umkm $\left(X_{1}\right)$ dan variabel lainnya konstan, maka akan meningkatkan nilai variabel berlakunya SAK EMKM (Y) sebesar 0,014. Sebaliknya setiap penurunan satu satuan variabel persepsi pelaku sentra Umkm $\left(\mathrm{X}_{1}\right)$ dan variabel lainnya konstan, maka akan menurunkan variabel berlakunya SAK EMKM (Y) sebesar -0,014.

$B_{2}=0,168 \quad$ artinya setiap penambahan satu satuan variabel pemahaman pelaku sentra Umkm $\left(X_{2}\right)$ dan variabel lainnya konstan, maka akan meningkatkan nilai variabel berlakunya SAK EMKM (Y) sebesar 0,168. Sebaliknya setiap penurunan satu satuan variabel pemahaman pelaku sentra Umkm $\left(\mathrm{X}_{2}\right)$ dan variabel lainnya konstan, maka akan menurunkan variabel berlakunya SAK EMKM (Y) sebesar - 0,168.

\section{Pengujian Hipotesis Parsial (Uji t)}

1. Pengujian Hipotesis Pertama (H1), Pengaruh Persepsi Pelaku Sentra UMKM terhadap Berlakunya SAK EMKM

Diketahui nilai Sig. untuk pengaruh Pesepsi Pelaku Sentra UMKM terhadap Berlakunya SAK EMKM adalah sebesar 0,269 >0,05 dan nilai $\mathrm{t}$ hitung 0,788 < t tabel 1,967 sehingga dapat diambil kesimpulan bahwa H1 ditolak dan H0 diterima. Artinya bahwa secara parsial tidak terdapat pengaruh Pesepsi Pelaku Sentra UMKM terhadap Berlakunya SAK EMKM.

2. Pengujian Hipotesis Kedua (H2), Pengaruh Pemahaman Pelaku Sentra UMKM terhadap Berlakunya SAK EMKM 
Diketahui nilai Sig. untuk pengaruh Pemahaman Pelaku Sentra UMKM terhadap Berlakunya SAK EMKM adalah sebesar 0,002 <0,05 dan nilai t hitung 3,160 > t tabel 1,967 sehingga dapat diambil kesimpulan bahwa $\mathrm{H} 2$ diterima dan $\mathrm{H} 0$ ditolak. Artinya bahwa secara parsial terdapat pengaruh Pemahaman Pelaku Sentra UMKM terhadap Berlakunya SAK EMKM.

Tabel 5 Hasil Analisis Regresi Berganda

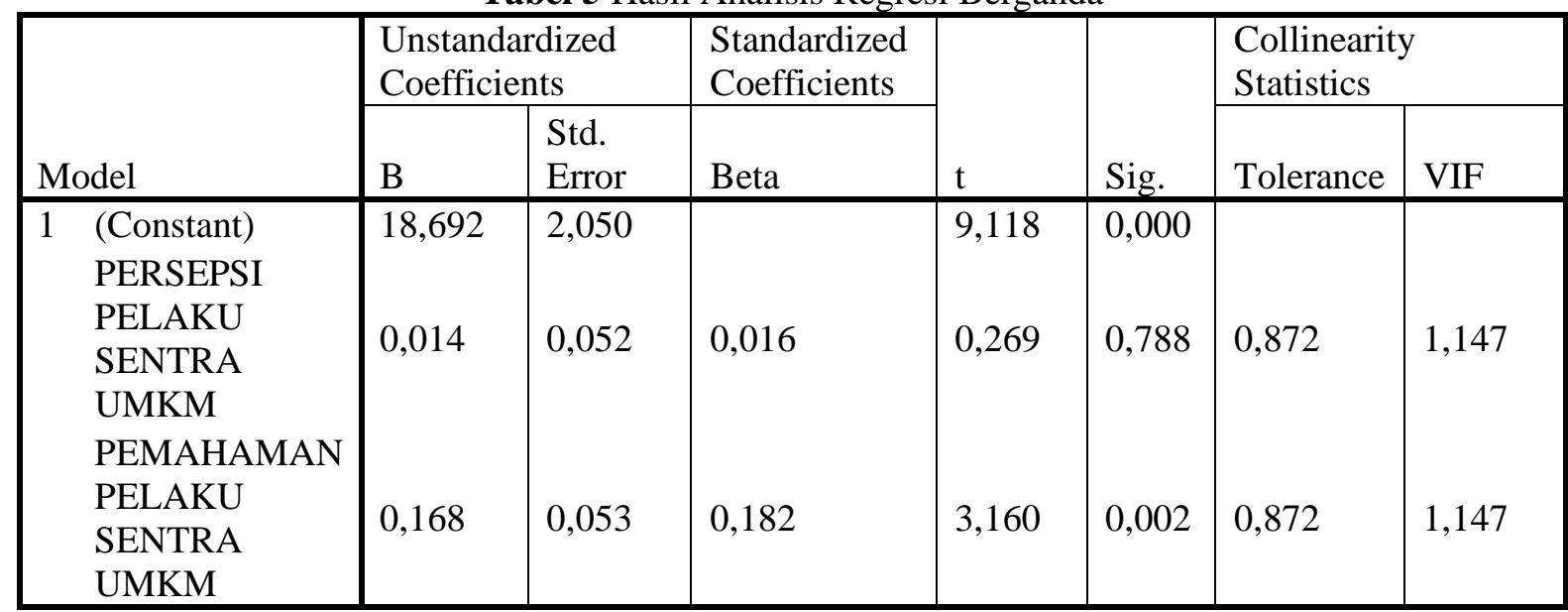

a. Dependent Variable: BERLAKUNYA SAK EMKM

\section{Pengujian Hipotesis Simultan (Uji F)}

Pengujian Hipotesis Ketiga (H3), Pengaruh Persepsi dan Pemahaman Pelaku Sentra UMKM terhadap Berlakunya SAK EMKM. Berdasarkan Uji F diatas diketahui nilai Sig. untuk Pengaruh Persepsi dan Pemahaman Pelaku Sentra UMKM terhadap Berlakunya SAK EMKM adalah sebesar 0,002 < 0,05 dan nilai $\mathrm{F}$ hitung 6,115 > F tabel 2,63 sehingga dapat diambil kesimpulan bahwa H3 diterima dan H0 ditolak. Artinya bahwa secara simultan terdapat Pengaruh Persepsi dan Pemahaman Pelaku Sentra UMKM terhadap Berlakunya SAK EMKM. Secara uji Koefisien Determinasi (R Square) menunjukan sebesar 0,035 yang artinya bahwa Pengaruh Persepsi dan Pemahaman Pelaku Sentra UMKM secara simultan terhadap Berlakunya SAK EMKM sebesar 3,5\% sedangkan sisanya sebesar 96,5\% dipengaruhi oleh faktor lain yang tidak diteliti dalam penelitian ini.

Tabel 6 Hasil ANOVA ${ }^{\mathrm{a}}$

\begin{tabular}{|ll|c|c|l|l|l|}
\hline & Model & Sum of Squares & df & Mean Square & F & Sig. \\
\hline 1 & Regression & 91,409 & 2 & 45,704 & 6,115 & $.002^{\mathrm{b}}$ \\
& Residual & 2488,731 & 333 & 7,474 & & \\
& Total & 2580,140 & 335 & & & \\
\hline
\end{tabular}

Model Summary ${ }^{\text {b }}$

\begin{tabular}{|c|c|c|c|c|c|}
\hline Model & $\mathrm{R}$ & R Square & $\begin{array}{c}\text { Adjusted } \\
\text { R Square }\end{array}$ & $\begin{array}{c}\text { Std. Error of } \\
\text { the Estimate }\end{array}$ & $\begin{array}{c}\text { Durbin- } \\
\text { Watson }\end{array}$ \\
\hline 1 & $.188^{\mathrm{a}}$ &, 035 &, 030 & 2,73380 & 1,513 \\
\hline
\end{tabular}

a. Predictors: (Constant), PERSEPSI PELAKU SENTRA UMKM, PEMAHAMAN PELAKU SENTRA UMKM

b. Dependent Variable: BERLAKUNYA SAK EMKM

\section{Pembahasan Penelitian}

1. Pengaruh Persepsi Pelaku Sentra UMKM Terhadap Berlakunya SAK EMKM

Berdasarkan hasil penelitian yang telah dilakukan menunjukan bahwa pengaruh persepsi pelaku sentra UMKM terhadap berlakunya SAK EMKM tidak berpengaruh secara parsial sesuai dengan Uji t yang menunjukan bahwa nilai $\mathrm{t}$ hitung $0,788<\mathrm{t}$ tabel 1,967. Hal ini sesuai juga dengan hasil responden 
yang menyatakan bahwa penyajian informasi akuntansi secara keseluruhan menujukan nilai yang rendah yaitu sebesar 758 , dan juga hasil penelitian ini tidak sesuai dengan yang dilakukan oleh Nurfadiah, dkk (2019)

2. Pengaruh Pemahaman Pelaku Sentra UMKM Terhadap Berlakunya SAK EMKM

Berdasarkan hasil penelitian yang telah dilakukan menunjukan bahwa pengaruh pemahaman pelaku sentra UMKM terhadap berlakunya SAK EMKM berpengaruh secara parsial sesuai dengan Uji t yang menunjukan bahwa nilai $\mathrm{t}$ hitung 3,160 > t tabel 1,967. Hal ini sesuai juga dengan hasil responden yang menyatakan bahwa memahmi proses pencatatan akuntansi menujukan nilai yang tinggi yaitu sebesar 1155, dan juga hasil penelitian ini telah sesuai dengan yang dilakukan oleh Kusuma \& Lutfiany (2018).

3. Pengaruh Persepsi Dan Pemahaman Pelaku Sentra UMKM Terhadap Berlakunya SAK EMKM Berdasarkan hasil penelitian yang telah dilakukan menunjukan bahwa persepsi dan pemahaman pelaku sentra UMKM secara simultan berpengaruh terhadap berlakunya SAK EMKM sesuai dengan Uji $\mathrm{F}$ yang menunjukan bahwa $\mathrm{F}$ hitung 6,115 > F tabel 2,63 dengan tingkat koefisien determinasi sebesar 0,035. Hal ini sesuai dengan hasil responden yang menunjukan baik persepsi dalam berlakunya SAK EMKM akan mendukung kepentingan usaha dengan skor 1453 maupun pemahaman terhadap proses pencatatan akuntansi dengan skor 1155 sehingga akan menghasilkan laporan keuangan yang dibutuhkan yaitu Laporan Posisi Keuangan, Laba Rugi, Catatan Atas Laporan Keuangan dengan skor 1330 dari skor ideal sebesar 1344.

\section{Kesimpulan}

Berdasarkan hasil dan pembahasan penelitian yang dilakukan dapat diambil kesimpulan bahwa pengaruh persepsi pelaku usaha sentra UMKM secara parsial tidak berpengaruh tehadap berlakunya SAK EMKM. Akan tetap pemahaman pelaku sentra usaha sentra UMKM secara parsial berpengaruh terhadap berlakunya SAK EMKM. Sedangkan secara simultan baik persepsi maupun pemahaman pelaku usaha sentra UMKM mempengaruhi berlakunya SAK EMKM.

\section{Daftar Pustaka}

DSAK IAI. (2016). Standar Akuntansi Keuangan Entitas Mikro, Kecil dan Menengah (SAK EMKM), Ikatan Akuntan Indonesia.

Fahmi, I. (2015). Analisis Laporan Keuangan. Bandung: Alfabeta.

Hetika \& Mahmudah, N. (2017). Penerapan Akuntansi dan Kesesuaian dengan SAK ETAP Pada

UMKM Kota Tegal. Jurnal Akuntansi, Ekonomi Dan Manajemen Bisnis, 5(2), 259-266.

Kasmir. (2014). Analisa Laporan Keuangan, Cetakan Ketujuh, Jakarta: PT Raja Grafindo Persada.

Kotler, P., Keller, K. L. (2013). Manajemen Pemasaran, Jilid Kedua, Jakarta: Erlangga..

Kusuma, C. I. \& Lutfiany, V. (2018). Persepsi UMKM Dalam Memahami SAK EMKM. Jurnal Akunida, 4(2), 1-14.

Ma'rifatul, I. A. (2012). Penerapan Akuntansi Berdasarkan SAK ETAP pada UMKM Kampung Batik Sidoarjo. Artikel Ilmiah: 1-5.

Nurfadilah, P., Diana, N., Mawardi, C. M. (2019). Pengaruh Pesepsi Pengusaha Mikro Kecil Menengah Dan Tingkat Pemahaman Terhadap Penggunaan SAK EMKM. E-JRA, 8(11), 116-128.

Sudjana, N. (2014). Penilaian Hasil Belajar, Bandung: Remaja Rosda Karya.

Sugiyono. (2017). Metode Penelitian Kuantitatif, Kualitatif, dan R\&D. Bandung: Alfabeta.

Sanusi, A. (2011). Metode Penelitian Bisnis. Jakarta: Salemba Empat.

Suyanti, D. (2013). Metodologi Penelitian Akuntansi. Bandung: PT Refika Aditama Anggota Ikapi.

Salmiah, N., Nanda, TS., \& Adino, I. (2018). Pemahaman Pelaku UMKM Terhdap SAK EMKM : Survey Pada UMKM Yang Terdaftar Di Dinas Koperasi Dan UMKM Kota Pekanbaru. Akuntansi Dewantara, 2(2), 194-204.

Sofiah, N. \& Murniati, A. (2014). Pesepsi Pengusaha UMKM Keramik Dinoyo Atas Informasi Akuntansi Keuangan Berbasis Entitas Tanpa Akuntabilitas Publik (SAK ETAP).

Trisomantagani, A. K., Yasa, P. I. N., \& Yuniarta, A. D. (2017). Persepsi Usaha Kecil dan Menengah Terhadap Kesiapan Dalam Menerapkan SAK EMKM. Jurnal Akuntansi Program S1, 8(2). 
Tambunan, T. (2012). Usaha Mikro Kecil dan Menengah di Indonesia : Isu-Isu Penting. Jakarta: LP3ES.

Umar, H. (2011). Metode Penelitian Untuk Skripsi dan Tesis Bisnis Edisi 11. Jakarta: PT Raja Grafindo Persada.

Undang-Undang No. 20 Tahun 2008 Tentang Usaha Mikro, Kecil dan Menengah.

*Email korespondensi:

Kasir

kasirinaba@gmail.com 